\title{
Mari Rusi-Pyykönen
}

\section{Lectio praecursoria:}

Hetkestä syntynyttä. Suunnanmuntoksia ja undenlaista otetta osallistavan teatterin käytäntöihin 


\section{Lectio praecursoria: \\ Hetkestä syntynyttä. Suunnanmuutoksia \\ ja uudenlaista otetta osallistavan teatterin \\ käytäntöihin}

Mari Rusi-Pyykönen

Kirjoitin väitöskirjani kiitokset lähes vuosi sitten. Työ oli tehty. Pitkäkestoisen tutkimusprosessin pääteasema siinsi horisontissa, vaan ei kuitenkaan. COVID-19-rajoitukset aiheuttivat äkkipysähdyksen. Oli kuin pohjoisesta Kolarin rautatieasemalta alkanut matkanteko olisi tyssännyt juuri ennen Pasilaa. Jouduin kasvokkain ennakoimattoman kanssa. Kulunutta puolen vuoden odotusta voisi kutsua kynnyksellä viipymiseksi käsillä olevan tilanteen ja tulevan - ei vielä olevan eikä tiedetyn - välissä.

Aika, tila ja ennakoimattomuus - tilanteellisina tekijöinä työskentelyssä - ovat myös taiteellisen tutkimukseni keskiössä. Tiedonintressini kohdentuu siihen, miten ennakoimattoman tilanteen tarjoamaa tilaisuutta ja siihen tarttumista voisi hyödyntää taiteellisen tutkimuksen tekemisessä ja osallistavan teatterin käytännöissä. Tarkastelen siten aikaa - mahdollisuutena.

Osallistavan teatterin käytäntöjen perimmäinen laatu, ontologia, muodostuu tilanteisuudesta, konkreettisista tilanteista ja tapahtumista. Nämä sisältävät läsnäoloa, suhteita ja yhteistä työskentelyä jaetun vuorovaikutuspiirin aistikentässä. Käytännöt todentuvat toiminnassa tässä ja nyt, siksi mielenkiinto tutkimuksessani kohdistuu tilanteesta lähtevään työskentelyyn ja siitä nousevaan tietoon. Tilannelähtöisyyteen liittyy väistämättömästi ennakoimattoman kohtaamista. Valmiiksi mallinnetuista työtavoista kokeilevaan ja tunnustelevaan työskentelyyn siirtyminen rakentuu tutkimusprosessini aikana yhdeksi keskeiseksi suunnanmuutoksen tekijäksi osallistavan teatterin uudenlaisiin käytäntöihin.

Tutkimukseni käsittelee institutionaalisen teatterin ulkopuolista, osallistavan teatterin toimintakenttää. Suomessa tällä kentällä työskentelyä on kutsuttu termeillä draama, draamakasvatus, draama \& teatteri. Näiden alkuosana on käytetty mm. sosiaalista-, soveltavaa-, osallistuvaa-, yhteisöl- 
listä. (Ks. esim. Ventola 2013.) Tutkimuksessani tarkastelen osallistavan teatterin käytäntöjä toimintakentässä, jonka jäsen olen. Tutkimukseni on kokemusperäistä ja tekijälähtöistä, ja sen perustana on tutkimuskohteen tuttuus. Ensikosketuksen osallistaviin draaman työtapoihin sain toimintaterapian opinnoissani 1970-luvun puolivälissä. Toimintaterapeuttikoulutuksessa "draaman" eli draamallisten menetelmien opetus toteutui lukukausittain systemaattisesti etenevänä ja syvenevänä juonteena. Paikannan tutkimuksessa omaelämäkerrallista tutkijakuvaani. Tutkimuksen tekemisen omaelämäkerrallisina aineksina on kokemushorisonttiini rakentunut kokemustieto ja sen kriittinen, refleksiivinen käyttö osana tutkimusta. Lähestymistapani on siten autoetnografinen (Chang 2008; Madison 2005).

Tutkimuksessani osallistava teatteri ei näyttäydy selkeärajaisena käsitteenä, genrenä tai työskentelytapana, vaan "osallistava” viittaa esitystapahtumassa mukanaolijoille tarjottavaan mahdollisuuteen osallistua vastavuoroiseen ja yhteisesti rakentuvaan työskentelyyn: ryhmän yhteisesti tuottamaan esteettisen prosessiin (vrt. Hughes ja Nicholson 2016; Ventola 2013). Siten toimintakenttään omaksuttuja käytänteitä verrataan tutkimuksessani ihmisten väliseen, yhteisyyttä ja aktiivista toimijuutta tukevaan osallistumiseen. Osallistavassa teatterissa osallistaminen on alusta asti yhdistetty yhteiskunnallisesti aktivistiseen asennoitumiseen ja yhteiskuntakriittiseen toimintaan (Rifkin 2010). Työskentelyssä se tarkoittaa osallistujien elämäntilanteen kokonaisvaltaista huomioon ottamista.

Kun työskentelyn jatkuvuus ja pitkäkestoisuus kuvasivat osallistavan taiteen ruohonjuuritason käytäntöjä sen ensimmäisinä vuosikymmeninä 1960-1980-luvuilla, alkoi projektimaisuus kuvata toimintatapaa 1990-luvulta alkaen (Bishop 2011). Tällöin uusliberalistisen kulttuuripolitiikan kehyksessä taidetta ja kulttuuria alettiin tarkastella menetelminä ja välineinä: esimerkiksi erilaisina palvelutuotteina sosiaalisen, kasvatuksellisen tai taloudellisen hyödyn tavoitteiden saavuttamiseksi (Haapalainen 2018; Mullen 2012; O'Connor ja Anderson 2015). On kuitenkin syytä tarkastella kriittisesti projektien ennalta määriteltyjä muutostavoitteita, sillä ihmisten elämäntilanteissa ja sosiaalisissa olosuhteissa on kyse huomattavasti monisyisemmistä ja monimutkaisemmista asioista kuin mihin määräaikaisilla, kertaluontoisiin rahoituksiin perustuvilla projekteilla voidaan vaikuttaa. Uudenlaisen tulokulman toimintakentän tutkimusprojekteihin tuo pitkäkestoinen ArtsEqual-hanke. Tutkimukseni näkökulmasta erityinen mielenkiinto kohdistuu sen yhteisötaiteellisen ryhmän työn tuloksiin.

Tutkimukseni taustalla on kentän nykyisestä kehityssuunnasta herännyt kysymys: etäännyttävätkö välineelliset tehtävät ja mallinnetut työtavat 
osallistavaa teatteria peruuttamattomasti sen alkuperäisestä yhteisöllisyydestä, kokeellisista työskentelyprosesseista ja radikalismista? Kysymykseen liittyy huoli ryhmälähtöisen ja prosessimaisen työskentelytavan elintilan säilymisestä nykyisessä hankekeskeisessä suuntauksessa. Osallistavalla prosessimaisella työskentelyllä, joka ei voi antaa lupauksia lopullisista tuloksista, esimerkiksi osallistujissa tapahtuvista muutoksista tai eheytymisistä, näyttää olevan vaikea sopia nykyisen hankemaailman tavoiteasetteluihin. Mikäli huomio toiminnassa keskittyy yksinomaan työskentelyn tavoitteisiin ja vaikutuksiin, jäävät esitystapahtuman aikana syntyneet aistimukselliset ja affektiiviset kokemukset sekä työskentelystä heränneet mielikuvat merkityksiltään toissijaisiksi.

Tutkimustehtäväni on uudistaa osallistavan teatterin käytäntöjä suhteessa työskentelyprosessin tilanteellisiin tekijöihin sekä ympäröivän aistihavaintokentän elementtien käyttämiseen työskentelyssä. Tutkimuksellisen työskentelyni lähtökohtana on metodinen kokeilevuus. Sitä luonnehtii tiedonintressi, joka pyrkii laaja-alaiseen tiedon hankintaan sekä uudenlaisiin, totutuista poikkeaviin asioiden jäsentämis- ja tarkastelutapoihin. Tämä tapahtuu limittäisten perspektiivien ja paradigmojen sisällä ja välissä. Metodologisessa orientaatiossani viittaan bricolage-käytäntöön (tee se itse -tekemiseen) ja sen toimijaan, eräänlaiseen "tee se itse -tutkijaan", ajattelun käsityöläiseen, joka suunnitelmallisesti ja itserefleksiivisesti rakentaa omia menetelmiään tutkimusta tehdessään (Rogers 2012; Kincheloe, McLaren ja Steinberg 2011). Onkin kuvattu, että taiteellisen tutkimuksen tekijät "veistävät" tutkimuksensa työvälineet prosessin aikana. Kuvaan oman tutkimustyöni toteutustapaa tekemisen ja ajattelun bricolage-käsityöläisyydeksi.

Tutkimukseni rakentuu kolmesta osasta:

1. osallistavan teatterin lähihistoriallisesta taustoituksesta,

2. Käsillä-nimisestä esineprojektista, tutkimuksen käytännöllisestä osasta sekä

3. tutkimuksen lopputuloksena ja johtopäätöksenä rakentuneesta eettis-poliittisesta sommitelmasta.

Taustoituksen tarkoitus on kirkastaa osallistavan teatterin käytäntöjen historiallista muotoutumista. Lisäksi se tarkastelee toimintakentän vakiintuneita käytäntöjä nykytilanteen näkökulmasta. Taustoitus toimii jäsentyneenä ennakkokuvana ja pohjana tutkimukseni seuraaville työskentelyvaiheille. Tutkimusmateriaalin keräämisen menetelmät ovat olleet kirjallisuuteen pohjaava kuvaus sekä ryhmämuistelu ja kentän asiantuntijatoimijoiden kanssa käydyt ryhmä-ja kahdenkeskiset keskustelut. 
Tutkimukseeni sisältyvän käytännöllisen osan Käsillä-esineprojektissa lähdin taiteelliselle tutkimukselle ominaisesti muuntamaan prosessidraamassa käyttämääni työtapaa tutkimukselliseksi työvälineeksi: tekemisen kautta tietämisen tavaksi. Taiteellisen tutkimuksen kentässä tutkimukseni paikantuu käytännön ohjaaman tutkimuksen alle (Haseman 2006). Prosessidraaman työpajoissani puhe ei ole keskeisin ilmaisullinen elementti, vaan työtavan erityisyytenä on sattumalta löydettyjen esineiden käyttäminen niiden omassa olemustavassaan esinetoimijoina tai alkusysäyksenä ja suuntana ryhmän tulevalle toiminnalle. Työskentelyprosessille on ominaista vähäeleisyys sekä episodimainen eteneminen. Prosessidraamalle luonteenomaisesti muoto rakentuu improvisaatiotyöskentelyn kuluessa (Eriksson 2011; Haseman 2002). Esinelähtöisessä työtavassa inhimilliset ja ei-inhimilliset esiintyjät ovat lähtökohtaisesti tasavertaisia (ks. Allen 2014).

Tutkimukseni esineprojektissa käyttämäni menetelmä oli prosessitöiden käsin tekeminen. Menetelmän tarkoituksena oli:

rakentaa kontekstia ja syvempää ymmärrystä esinelähtöiselle, havainnoimisen ruumiillisuutta ja aistisuutta painottavalle työskentelytavalle osallistavassa prosessissa.

koetella esinelähtöisen käsillä tekemisen kautta tapahtuvaa tutkimuksellista ajatteluprosessia ja kuvata prosessitöiden omakohtainen tarkasteluprosessi taiteellisen tutkimuksen tekemisessä.

Prosessitöiden materiaalisena lähtökohtana olivat vanhat, jokapäiväisessä käyttötarkoituksessaan kuluneet ja sittemmin hylätyt esineet. Suhteeni esineisiin sisälsi olettamuksen, että jokainen esine omassa olemistavassaan voi pitää sisällään taiteellista tai tutkimuksen käytäntöön liittyvää ideaa.

Prosessitöiden valmistamisen käsillä työskentely voidaan itsessään nähdä omanlaisena tapana ajatella. Se on ruumiillista ajattelua, jossa käsi viestii aivoille ja aivot kädelle. Käden työ perustuu ajatteluun. Käsin ajattelu on ihmiselle yhtä olennainen piirre kuin kyky käsitteelliseen ajatteluun. Näiden ero on se, että käsin tekemisessä tieto ei lähde valmiista käsitteistä, ajatuksesta tai muodosta. Sen sijaan tieto kasvaa työskentelyn prosessissa ihmisen aistimuksellisesta havaitsemisesta yhteistyössä materiaalien ja ympäristön kanssa. (Ks. Ingold 2013; Pallasmaa 2009; Siukonen 2011.)

Töiden valmistamisessa keskeistä oli käsillä tekemisen kautta rakentuva ajattelu ja sen tuottamat, tutkimusprosessiin yhdistyvät oivallukset ja ymmärrykset. Pyrkimyksenä oli etsiä materiaalista ilmaisua tutkimustehtävään liittyville ajatuksille. Prosessitöiden valmistaminen oli kulultaan kokeilevaa materiaalis- konkreettista toimintaa. Sen tuloksena syntyi yhdeksän prosessityön esinekoostetta, assemblaasia. 
Töiden retrospektiivisessä tarkastelussa rakentui prosessityömetodi ja sen kolme kulmakiveä. Kulmakivet painottavat 1) esineeseen luotua suhdetta (esinekumppanuutta), 2) aistimuksellisten mielikuvien osuutta ajatteluprosessissa ja 3) esineiden välisestä montaasimaisesta rinnastamisesta syntyvää uusien merkitysten syntymistä.

Esineiden kanssa työskentely tarjosi mahdollisuuden syventyä tarkastelemaan löytöesineiden ja ihmisruumiillisuuden omaamaa vertailtavuutta, vertauskuvallisuutta ja samankaltaisuutta niissä tilanteissa, joissa oleminen maailman kanssa rikkoutuu. Kuluneiden ja vahingoittuneiden löytöesineiden kohtalot tehtävästään orpoutuneina vertautuvat tutkimuksessani ihmiselämän ruumiillisuuteen: sen särkyvyyteen ja rajallisuuteen. Esiin tulee esineen ja ihmisen samankaltaisuus. Esineiden käsin kosketeltavien ominaisuuksien ymmärtäminen on myös yritystä ymmärtää niiden kykyä koskettaa meitä affektiivisesti. Aistihavainto on suhteessa olemista esineeseen ja sen ominaisuuteen. Tähän suhteessa olemiseen liitän prosessitöitteni kuluneisuuden estetiikan. Se edustaa köyhyyden ja kuluneisuuden kokemuksellista arvoa töissäni ja myös tapaa katsoa ympäröivää maailmaa ja itseämme.

Aistimukselliset mielikuvat ovat keskeisiä esinelähtöisessä käsin tekemisen menetelmässä. Esineiden kanssa työskentelyssä aistimukset, muistot, mielikuvat ja mielikuvitus aktivoituvat ja yhdistyvät (vrt. Turunen 1998). Näin ne synnyttävät uusia mielleyhtymiä ja ajatuskulkuja: virittävät ja yhdistelevät ajatuksia, käsitteitä, tapahtumia ja tunnetiloja.

Prosessitöiden tekeminen oli esinelähtöisestä käytännöstäni ja käsin tekemisen kautta tietämisen ideasta rakentuneen metodin kokeilua tutkimusprosessini ymmärtämiseksi ja ohjaamiseksi. Työt ilmentävät aistimuksellisen havaintopohjaisen ajattelun ja siitä syntyneiden mielikuvien esineellistymistä, kun arkipäiväinen esine ja tutkimukseen liittyvä kysymys törmäävät (vrt. Siukonen 2011). Prosessityöt ja niiden synnyttämät ajatukset ja mielleyhtymät tuottivat teemoja ja näkökulmia tutkimukseeni.

Tutkimuksen kolmannen vaiheen tuloksena ja tutkimusprosessini johtopäätöksenä rakentui eettis-poliittinen_sommitelma. Se rakentuu viidestä elementistä, joista avautuu uudenlainen perspektiivi osallistavan prosessin tilannesidonnaisuuteen, aistimellisuuteen, ennakoimattomuuteen sekä ohjaajan ja ryhmän vastavuoroisuuteen. Sommitelman elementit auttavat purkamaan toiminnassa kaavamaisia ja tasavertaisen työskentelyn kannalta ongelmallisiksi käyneitä asetelmia ja käytäntöjä. Sommitelmassa painotetaan tapahtumiselle tilaa antavia työtapoja, jotka eivät ennalta määrittele sisältöjä, osallistujien välisiä suhteita tai yhteenliittymisen tapoja. Sommitelman rakentamisen keskeinen metodi pohjasi montaasiteoriaan (ks. Huttunen 1997). Se mahdollisti tutkimusmateriaalin sisältämien erilaisten 
ainesten, asioiden ja näkökulmien rinnastamisia ja yhdistämisiä uusien kokonaisuuksien ja merkityksien aikaansaamiseksi.

Väitöskirjassani ehdotan uutta suuntaa tutkimukselle: mikäli osallistavan teatterin kentän monimuotoisuutta halutaan suojella, niin tutkimuksissa on tärkeä syventyä tarkastelemaan juuri tätä monimuotoisuutta. Samalla muokataan maaperää uudenlaisille käytännöille.

Tästä lektiosta käynnistyi viimeinen etappi kohti tutkimusprosessini pääteasemaa.

\section{Lähteet}

Allen, Richard. 2014. Theatre Machines. A practice-based enquiry into the performance of objects. Wales: Aberystwyth University

Bishop, Claire. 2012. Artificial Hells. Participatory art and the politics of spectatorship. London: Verso.

Chang, Heewon. 2008. Autoethnography as Method. Walnut Creek: Left Coast Press.

Eriksson, Stig. 2011. "Distancing at Close Range: making strange devices in Dorothy Heathcote's process drama Teaching Political Awareness Trough Drama." Research in Drama Education: The Journal of Applied Theatre and performance. Vol. 16 (1). London: Routledge, 101-123.

Haapalainen, Riikka. 2018. Utopioiden arkipäivää osallistumisen ja muutoksen paikkoja nykytaiteessa 1980-2011. Väitöskirja. Helsingin Yliopisto. Humanistinen tiedekunta.

Haseman, Brad. 2002. "The Leaderly Process Drama and the Artistry of 'Rip, Mix and Burn'”. Teoksessa Bjørn Rasmussen ja Anna-Lena Østern (toim.): Playing Betwixt and Between. The IDEA Dialogues 200, 226-231. Bergen: IDEA Publications and IDEA 2001 World Congress.

Haseman, Brad. 2006. "A Manifesto for Performative Research". Media International Australia incorporating Culture and Policy, theme issue "Practice-led Research" (118), 98-106.

Hughes, Jenny ja Helen Nicholson. 2016. "Applied Theatre. Ecology of practices." Teoksessa Jenny Hughes and Helen Nicholson (toim.): Critical Perspectives on Applied Theatre, 1-12. Cambridge: Cambridge University Press.

Huttunen, Tomi. 1997. "Montaasi ja teksti." Synteesi (4), 58-79.

Ingold, Tim. 2013. MAKING. Anthropology, Archaeology, Art and Architecture. London: Routledge.

Kincheloe, Joe. L., Peter McLaren ja Shirley R. Steinberg. 2011. "Critical Pedagogy and Qualitative Research: Moving to the Bricolage." Teoksessa Norman Denzin ja Yvonna S. Lincoln (eds.) 2011: The SAGE Handbook of Qualitative Research. (4. ed.), 163-177. New York: SAGE. 
Madison, D. Soyni. 2005. Critical ethnography: Method, ethics, and performance. CA, Thousand Oaks: SAGE.

Mullen, Molly. 2012. "Taking care and playing it safe: Tension in the management of funding relationships." Journal of Arts Eं Communities. Vol. 4. (3), 181-198.

O’Connor, Peter ja Michael Anderson. 2015. "Research in a Post-Normal World." Teoksessa Peter O'Connor ja Michael Anderson (toim.): Applied Theatre Research. Radical Departures, 3-94. London: Bloombury.

Pallasmaa, Juhani. 2009. The Thinking Hand: Existential and Emboded Wisdom in Archtecture. Chichester: John Wiley \& Sons.

Rifkin, Frances. 2010. The Ethics of Participatory Theatre in Higher Education. A Framework for Learning and Teaching. The Higher Education Academy. PALATINE - Dance, Drama and Music. Lancaster University.

Rogers, Matt. 2012. "Contextualizing Theories and Practices of Bricolage Research." The Qualitative Report. 2012 Vol. 17, T\&L Art. 7, 1-17. University of New Brunswick. http://www.nova.edu/ssss/QR/QR17/rogers.pdf

Siukonen, Jyrki. 2011. Vasara ja hiljaisuus. Lyhyt johdatus työkalujen filosofiaan. Helsinki: Kuvataideakatemia.

Turunen, Kari. 1998. Minusta näyttää - johdatus reflektiiviseen filosofiaan. Jyväskylä: Atena.

Ventola, Marjo-Riitta. 2013. Osallistava teatteri. Laadukas aikalaiskonsepti. Lisensiaatintutkimus. Esittävien taiteiden tutkimuskeskus. Helsinki: Teatterikorkeakoulu. 